\title{
PENGEMBANGAN MEDIA INTERAKIF PADA PEMBELAJARAN MATEMATIKA BERBASIS KOMPETENSI ABAD 21
}

\author{
Sumiyati, Nurul Anriani, Yani Setiani \\ Universitas Sultan Ageng Tirtayasa, Jl. Raya Jakarta Km 4, Banten 15810, Indonesia \\ Email: sumiyati1333@gmail.com
}

\begin{abstract}
Abstrak
Tujuan dari penelitian ini adalah untuk menghasilkan media pembelajaran berupa powerpoint interaktif yang berbasis kompetensi abad 21 pada materi segiempat kelas VII SMP/MTs semester genap. Jenis penelitian ini merupakan penelitian pengembangan atau Research and Development (R\&D). Model pengembangan yang digunakan pada penelitian ini mengacu pada model pengembangan menurut Borg dan Gall yang meliputi tujuh langkah pokok, yaitu: analisis kebutuhan, kemampuan peneliti sebagai pengembang, produk yang dikembangkan, konsep produk, pengembangan produk, uji ahli dan uji coba lapangan. Hasil penelitian produk media pembelajaran berupa powerpoint interaktif berbantuan iSpring Suite. Hasil uji kelayakan media pembelajaran ini diperoleh berdasarkan data dari angket penilaian para ahli, yaitu ahli media, ahli materi dan ahli bahasa. Hasil dari ahli media yaitu 87,5\%, dari ahli materi 80,62\%, dari ahli bahasa 82,69\%, semua penilaian para ahli mencapai kategori sangat layak. Sedangkan kepraktisan media pembelajaran diperoleh dari data angket penilaian guru matematika yang hasilnya didapat $77,5 \%$ mencapai kategori sangat layak. Dapat disimpulkan bahwa secara keseluruhan media ini layak digunakan dalam kegiatan pembelajaran matematika.
\end{abstract}

Kata kunci: media interaktif, pembelajaran matematika, kompetensi abad 21

\begin{abstract}
The purpose of this research is to produce learning media in the form of interactive powerpoints based on 21st century for the material of quadrangle for class VII SMP / MTs last term. The type of this research is Research and Development (R\&D). The development model used in this research refers to the development model according to Borg and Gall which includes seven main steps, they are: needs analysis, the ability of researchers as developers, products developed, product concepts, product development, expert testing and field trials. The results of the reseach of learning media products in the form of interactive powerpoints assisted by iSpring Suite 8 based on 21st century. The results of the feasibility test for this learning media were obtained based on data from an assessment questionnaire by experts, namely media experts, material experts and linguists. Results from media experts were $87.5 \%$, from material experts $80.62 \%$, from linguists $82.69 \%$, all expert evaluations reached the very feasible category. While the practicality of instructional media is obtained from the mathematics teacher assessment questionnaire data which results obtained $77.5 \%$ reach the very feasible category. It can be concluded that overall interactive media is suitable for use in mathematics learning activities.
\end{abstract}

Keywords: interactive media, mathematics learning, 21st century competencies

\section{Pendahuluan}

Matematika merupakan ilmu yang sangat penting untuk dipelajari dari tingkatan SD bahkan sampai tingkatan perguruan tinggi [1]. Dengan mempelajari ilmu matematika kita mampu memahami karakteristiknya yang abstrak, tentu tidak mudah dan membutuhkan waktu yang cukup lama serta keseriusan dan penuh konsentrasi yang tinggi. Karena tanpa adanya keuletan dan keseriusan dalam mempelajarinya kita tidak akan mencapai keberhasilan dan tidak akan mampu memahaminya [2]. 
Keberhasilan suatu pembelajaran dapat dilihat dari tercapainya suatu tujuan pembelajaran. Berikut tujuan pembelajaran matematika berdasarkan Peraturan Kementerian Pendidikan dan Kebudayaan Republik Indonesia nomor 22 tahun 2006 adalah: 1) memahami konsep matematika, menjelaskan keterkaitan antar konsep dan mengaplikasikan konsep atau algoritma secara luwes, akurat, efisien, dan tepat dalam pemecahan masalah, 2) menggunakan penalaran pada pola dan sifat, melakukan manipulasi matematika dalam membuat generalisasi, menyusun bukti, atau menjelaskan gagasan dan pernyataan matematika, 3) memecahkan masalah, 4) mengkomunikasikan gagasan dengan symbol, tabel, diagram, atau media lain untuk memperjelas keadaan atau masalah, dan 5) memiliki sikap menghargai kegunaan matematika dalam kehidupan, sikap rasa ingintahu, perhatian, dan minat dalam mempelajari matematika, serta sikap ulet dan percaya diri dalam pemecahan masalah. Dari beberapa tujuan tersebut, terdapat tujuan pembelajaran matematika kompetensi 4C yang dibutuhkan dalam kompetensi abad 21.

Berdasarkan fakta dari hasil studi TIMSS dan PISA, skor rata-rata matematika Indonesia masih dibawah skor rata-rata Internasional. Maka dari itu, keseriusan yang tinggi dalam belajar diperlukan untuk mencapai pendidikan matematika yang baik, masih banyak permasalahan yang dialami dan harus diselesaikan. Peneliti melakukan analsis kebutuhan kepada beberapa guru matematika yang sedang melaksanakan kuliah pascasarjana di Universitas Sultan Ageng Tirtayasa didapatkan bahwa permasalahan yang berada pada proses kegiatan pembelajaran diantaranya adalah (1) cara menggunakan metode yang kurang bervariasi dalam pembelajarannya, (2) guru cenderung ingin praktis saja, enggan membuat dan menggunakan media dalam pembelajarannya, (3) hasil belajar selalu menjadi pegangan dalam keberhasilan suatu proses pembelajaran, (4) tidak memperhatikan peserta didik dalam proses belajarnya, (5) kurang memberikan rasa nyaman sehingga pesesrta didik tidak mau belajar matematika. Oleh karena itu, peserta didik merasa belajar matematika itu membosankan, monoton, rumit dan kurang kreatif [3].

Permasalahan lain juga yaitu proses pembelajaran disekolah masih banyak guru dalam mengajar matematika tidak melakukan pembelajaran bermakna. Pendidik yang kompeten dibidangnya akan menghasilkan peserta didik yang berhasil. Salah satunya yaitu pendidik tersebut mampu mengembangkan suatu bahan ajar atau media pembelajaran untuk proses pembelajarannya agar peserta didik tidak merasa bosan menemui dan belajar dengan bahan ajar yang terbatas, seperti buku pelajaran yang dianggap monoton dan sulit untuk dimengerti [4].

Memasuki abad 21 atau abad yang penuh tantangan didalamnya, artinya banyak sekali perubahan-perubahan yang fundamental yang dialami oleh manusia pada abad 21 ini, tentunya sangat berbeda dengan kehidupan-kehidupan pada zaman sebelum abad 21 ini. Dikatakan abad 21 karena secara tidak sadar banyak perubahan yang dialami manusia pada kehidupannya, semua usaha dan hasil yang dikerjakakan oleh manusia harus menghasilkan kualitas yang bagus. Oleh karena itu, dengan bergulirnya waktu abad 21 ini menginginkan sumber daya manusia yang sangat berkualitas, yang diperoleh dari lembaga-lembaga yang mengelolanya dengan professional sehingga

JARME, Volume 3, No. 1, Januari 2021, 43 - 53. 
sumber daya manusia yang dihasilkan memiliki kemampuan yang unggulan. Tuntutan yang baru tersebut meminta segala macam unggulan yang mampu berpikir, menyusun konsep, dan melakukan tindakan-tindakan yang nyata. Dengan kata lain untuk menghadapi tantangan-tantangan yang baru diperlukan paradigma yang baru juga.

Menurut penelitian [5] dalam penelitiannya mengemukakan bahwa dalam melaksanakan pembelajaran matematika yang berorientasi pada kompetensi abad 21 guru masih mengalami kesulitan. Berdasarkan hasil survei terbatas guru-guru matematika di Kota Serang Banten, masalah tersebut sangat bervariasi, diantaranya adalah lemahnya pengetahuan dan kemampuan untuk merencanakan, melaksanakan dan mengevaluasi hasil pembelajaran matematika yang berorientasi pada kompetensi abad 21. Maka dari itu, guru dituntut mampu menciptakan inovasi baru untuk pembelajaran matematika supaya peserta didik mempunyai keinginan dan tertarik untuk belajar dan memahami ilmu matematika ketika proses pembelajaran sedang berlangsung. Terkait hal tersebut, di abad 21 ini pendidikan matematika membutuhkan sumber daya manusia yang berkualitas, mempunyai kemampuan komparatif, inovatif, komfetitif yang tinggi dan mampu bekerjasama, sehingga ada bekal untuk menghadapi perubahan zaman yang semakin cepat ini [6].

Pemanfaatan tekknologi yang sudah canggih pada era sekarang ini memberikan dampak positif untuk para pengajar, karena itu semua bisa dijadikan alat bantu mengajar para pendidik. Hal ini pun tertuang dalam kurikulum 2013 tentang implementasi pembelajaran yang berbasis pada abad 21, pembelajaran pada abad ini harus mengintegrasikan kemampuan literasi, mempunyai kecakapan pengetahuan, ketreampilan dan sikap yang baik, dan selain itu harus mampu menguasai teknologi. Pengajar dituntut harus mampu menguasai dan menjalankan suatu teknologi agar terciptanya proses pembelajaran pada abad 21 ini menjadi lebih aktif, mudah, memperindah, mempercepat, dan mampu meningkatkan minat belajar peserta didik.

Berdasarkan permasalahan-permasalahan tersebut dan hasil survei di lapangan tentang analisis kebutuhan media pembelajaran matematika, maka perlu dikembangkan media pembelajaran matematika yang berbasis pada kompetensi abad 21. Media pembelajaran yang berbasis pada kompetensi abad 21 diharapkan dapat membantu guru menyelesaikan permasalahan yang sesuai dengan langkahlangkahnya, dan dapat digunakan sebagai media yang mengaktifkan siswa. Sehingga siswa dapat memahami konsep matematika dan memiliki kecakapan berpikir abad 21 . Contoh materi yang ada kaitannya dalam kehidupan sehari-hari siswa yang berorientasi pada kompetensi abad 21 adalah materi Segiempat. Adapun tujuan penelitian ini adalah menghasilkan media interaktif pada pembelajaran matematika berbasis kompetensi abad 21 yang layak digunakan untuk pembelajaran matematika.

\section{Metode}

Penelitian ini merupakan jenis penelitian pengembangan atau Research and Development (R\&D). R \& D adalah metode penelitian yang digunakan untuk menghasilkan produk tertentu, dan menguji keefektifan produk tersebut [7]. 
Model pengembangan yang digunakan didalam penelitian ini mengacu pada model pengembangan Borg and Gall [8] yang memaparkan sepuluh langkah. Namun, pada penelitian ini menerapkan tujuh langkah karena disesuaikan dengan kemampuan dan kebutuhan peneliti. Tujuh tahap tersebut yaitu: 1) Analisis Kebutuhan, 2) Kemampuan Peneliti Sebagai Pengembang, 3) Produk yang Dikembangkan, 4) Konsep Produk, 5) Pengembangan Produk, 6) Uji Ahli, dan 7) Uji Coba. Dengan demikian, pada penelitian ini langkah-langkah metode penelitian dapat digambarkan pada Gambar 1 berikut ini:

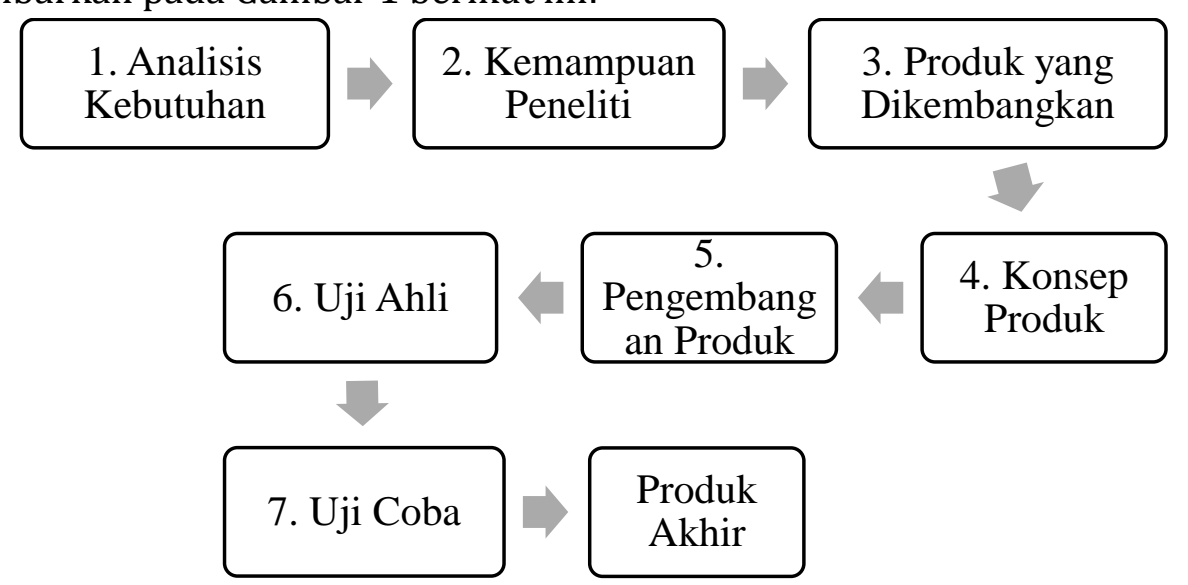

Gambar 1. Tujuh Langkah Penggunaan Metode R\&D Model Borg \& Gall

\subsection{Subjek Penelitian}

Pase Subjek uji coba yang akan digunakan adalah guru matematika yang mengajar di jenjang SMP/MTs.

\subsection{Pengumpulan Data}

Instrumen yang digunakan untuk mengevaluasi media pembelajaran yang dihasilkan dalam penelitian pengembangan ini berupa angket. Angket merupakan teknik pengumpulan data yang dilakukan dengan cara memberi seperangkat pertanyaan atau pernyataan tertulis kepada responden untuk dijawab [7]. Angket yang digunakan dalam penelitian ini yaitu angket uji ahli dan angket uji coba produk. Angket digunakan untuk mengumpulkan hasil tanggapan dari ahli media, ahli materi, ahli bahasa dan guru matematika.

\subsection{Analisis Data}

Cara menganalisis data menggunakan metode skala likert. Data hasil penelitian ini berupa hasil tanggapan dan masukan dari ahli media, ahli materi, ahli bahasa dan guru matematika terhadap kualitas media pembelajaran matematika yang berbasis kompetensi abad 21 ini berupa skor yang kemudian dikonversikan ke dalam skala Likert. Selanjutnya data yang diperoleh diolah untuk mendeskripsikan hasil angket pada tiap-tiap aspek dan menghitung persentase secara keseluruhan. 


\section{(2) Hasil dan Diskusi}

Pengembangan ini menghasilkan media pembelajaran interaktif powerpoint berbantuan iSpring suite 8 untuk pembelajaran SMP kelas VII. Proses pengembangan media pembelajaran interaktif pada pembelajaran matematika berbasis kompetensi abad 21 ini mengikuti langkah-langkah Borg and Gall sampai tahap ke-tujuh. Ke-tujuh langkah tersebut adalah sebagai berikut:

\section{(1) Analisis Kebutuhan}

Pada tahap studi pustaka, peneliti melakukan survei terbatas mengenai analisis kebutuhan guru kebeberapa guru yang sedang melakukan studi pascasarjana di UNTIRTA. Dari survei tersebut diperoleh informasi tentang kurangnya penggunaan media untuk proses pembelajaran, kurangnya menggunakan instrumen penilaian High Order Thinking Skills (HOTS) serta kurang menunjangnya buku paket dan buku pegangan lainnya yang digunakan oleh guru untuk proses pembelajaran bersama siswa. Pada tahap studi lapangan diperoleh informasi bahwa guru dan siswa belum terbiasa menggunakan penilaian HOTS sehingga siswa belum bisa terlatih untuk berpikir tingkat tinggi. Oleh karena itu dibutuhkan media pembelajaran untuk menjembatani siswa dalam kemampuan abad 21 itu.

(3) Kemampuan Peneliti sebagai Pengembang

Setelah dilakukan tahap analisis kebutuhan. Maka selanjutnya pada tahap ini, peneliti mencoba menentukan media yang akan dikembangkan secara mandiri.

(4) Produkyang dikembangkan

Pada pengembangan ini, media yang dikembangkan yaitu berupa media interaktif pada pembelajaran matematika dengan menggunakan aplikasi powerpoint berbantuan software iSpring suite 8 berbentuk trial yang dapat mengoptimalkan guru dalam kegiatan pembelajaran untuk mencapai kompetensi abad 21.

\section{(5) Konsep Produk}

Pada tahap ini peneliti merancang desain media pembelajaran dengan menentukan materi yaitu bangun datar segiempat. Menentukan menu-menu yang terdapat didalam powerpoint serta dilengkapi dengan flipbook atau buku digital dan kuis yang mengacu pada kompetensi abad 21 didalamnya. Kompetensi abad 21 yang digunakan dalam pengembangan buku ajar ini adalah kompetensi 4C, yaitu: kompetensi komunikasi (communication), kolaborasi (collaboration), berpikir kritis dan memecahkan masalah (critical thinking and problem solving), kreatif dan inovatif (creativity and innovation). Soal-soal yang disajikan juga berupa soal konstektual yang mengarah kepada kompetensi abad 21. 


\section{(6) Pengembangan Produk}

Secara garis besar, pengembangan media interaktif pada pembelajaran matematika berbasis kompetensi abad 21 yang disajikan berbentuk powerpoint yang sudah diubah kedalam bentuk html terdiri dari 10 slide yaitu: (1) Halaman Pembuka (2) Menu Utama (3) Menu Petunjuk (4) Menu Kompetensi (5) Menu Materi (6) Menu Kuis (7) Menu Glosarium (8) Menu Daftar Pustaka (9) Menu Profil (10) Menu Penutup.

A. Halaman Pembuka

Halaman pembuka meliputi sasaran penggunaan, identitatas media yaitu nama media dan materi yang akan disajikan, terdapat tombol navigasi yang terdiri dari tombol start, tombol putar, tombol maximize layar, tombol volume, tombol kembali dan tombol selanjutnya.

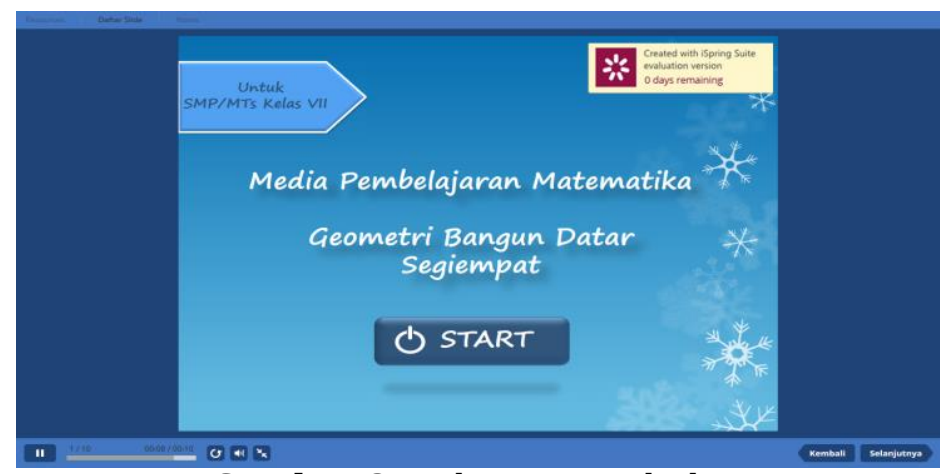

Gambar 2. Halaman Pembuka

B. Menu Utama

Menu utama yaitu menu yang dirancang agar pengguna bebas memilih menu yang akan dituju atau menu yang akan dipilih.

C. Menu Petunjuk

Menu petunjuk berisi keterangan tentang tombol-tombol navigasi yang terdapat didalam media pembelajaran. Tombol navigasi yang dirancang adalah tombol rumah, tombol keluar, tombol kembali dan tombol selanjutnya.

D. Menu Kompetensi

Menu kompetensi yaitu berisi kompetensi yang harus dicapai oleh siswa.

E. Menu Materi

Menu materi ini disajikan berupa flipbook yang meliputi: (1) cover buku, (2) peta konsep, (3) mengenal tokoh, dan (4) isi bab, contoh soal, ayo berlatih dan rangkuman. 


\section{Cover Buku, Peta Konsep dan Mengenal Tokoh}

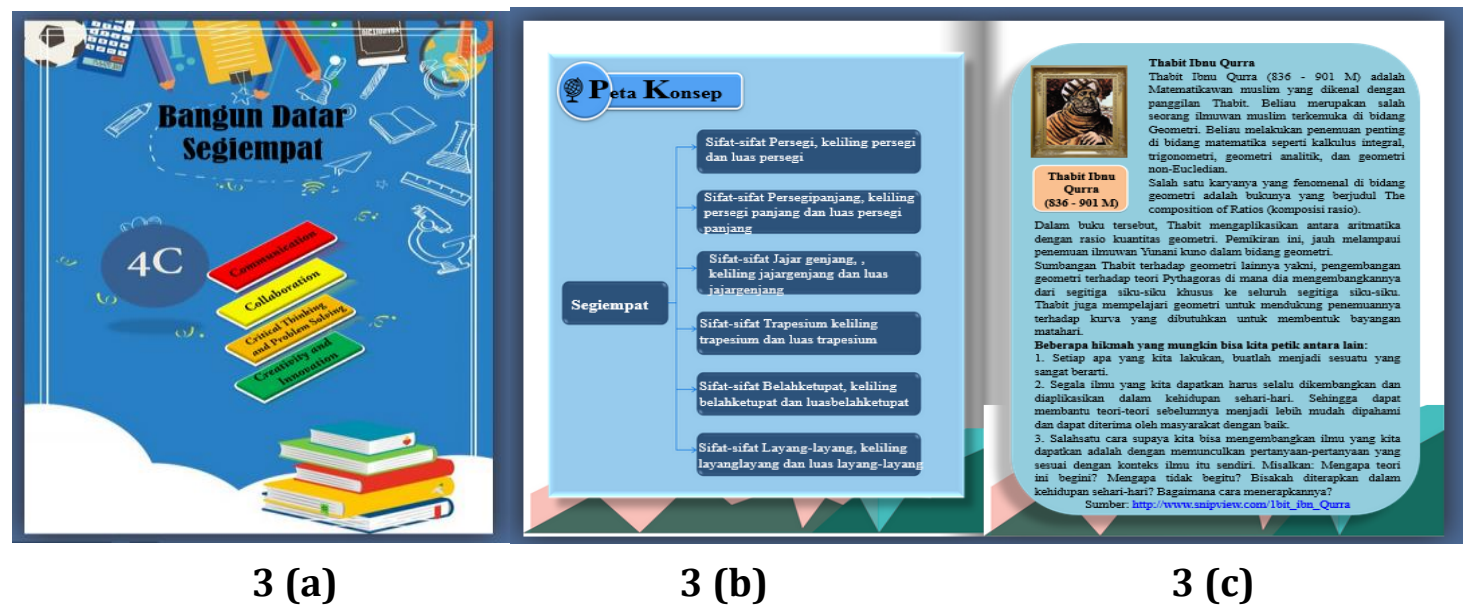

Gambar 3(a) Tampilan Cover Bab Segiempat, 3(b) Peta Konsep Bab Segiempat, 3(c) Tampilan Mengenal Tokoh Geometri

\section{Isi Bab, Contoh Soal, Ayo Berlatih dan Rangkuman}

Isi bab pada materi segiempat ini terdiri dari enam subbab yaitu persegi panjang, persegi, jajargenjang, trapesium, belahketupat dan laying-layang.

Subbab pertama yaitu disajikan berbagai gambar segiempat yang terdapat dikehidupan sehari-hari, untuk menumbuhkan kemampuan berpikir kritis siswa diminta mencari benda-benda yang berbentuk segiempat lalu dikelompokan berdasarkan jenisnya, dan dicari tahu persamaan dan perbedaannya secara sistematis. Salah satu kesimpulan yang didapat pada kegiatan tersebut yaitu mengetahui apa itu segiempat.

Selanjutnya siswa dihantarkan untuk mengetahui pengertian, sifat-sifat, keliling dan luas dari setiap subbab. Misalkan di subbab pertama yaitu persegi dan persegipanjang, maka siswa diminta mengamati gambar yang ada, lalu menuliskan apa saja yang didapatkan dari pengamatan gambar tersebut untuk mendapatkan kesimpulan apa yang dimaksud persegi dan persegipanjang, sifat-sifatnya, keliling dan luas persegi dan persegipanjang. Setelah menyelesaikan pengamatannya dan mendapatkan hasilnya, setiap kelompok diarahkan untuk menyampaikan hasil diskusinya berupa kesimpulan berdasarkan hasil analisis secara lisan, tertulis, atau media lainnya. Setelah itu, berikan kesempatan kelompok lain untuk menanggapi. Hal ini diharapkan dapat menumbuhkan kemampuan komunikasi dan kolaborasi. 


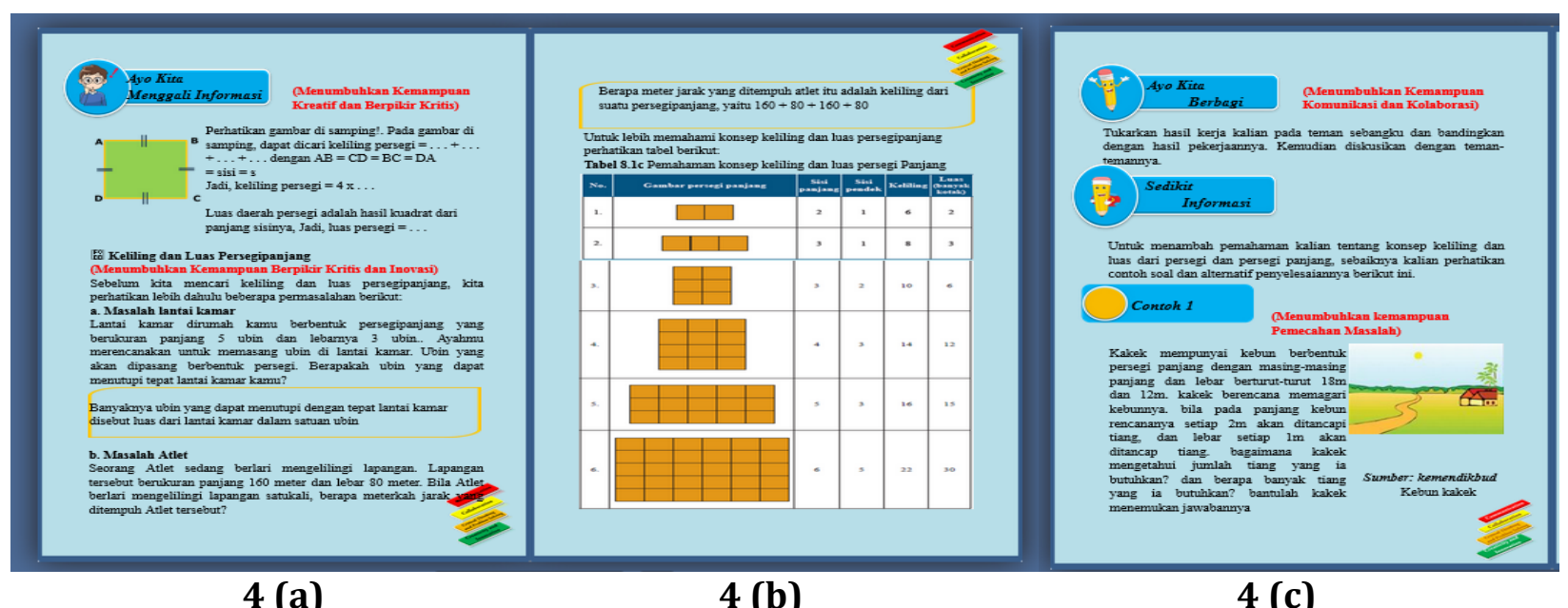

Gambar 4(a) dan 4(b) Ayo Kita Menggali Informasi, Gambar, 4(c) Ayo Kita Berbagi

Selanjutnya, setiap subbab diberikan contoh soal beserta penyelesaiannya. Selain itu terdapat juga evaluasi "Ayo Berlatih" berisi soal yang berkaitan dengan subbab yang dibahas dan mengacu pada indikator 4C. dan diakhir setiap subbab dilengkapi dengan rangkuman untuk merivew semua materi yang telah dipelajari.

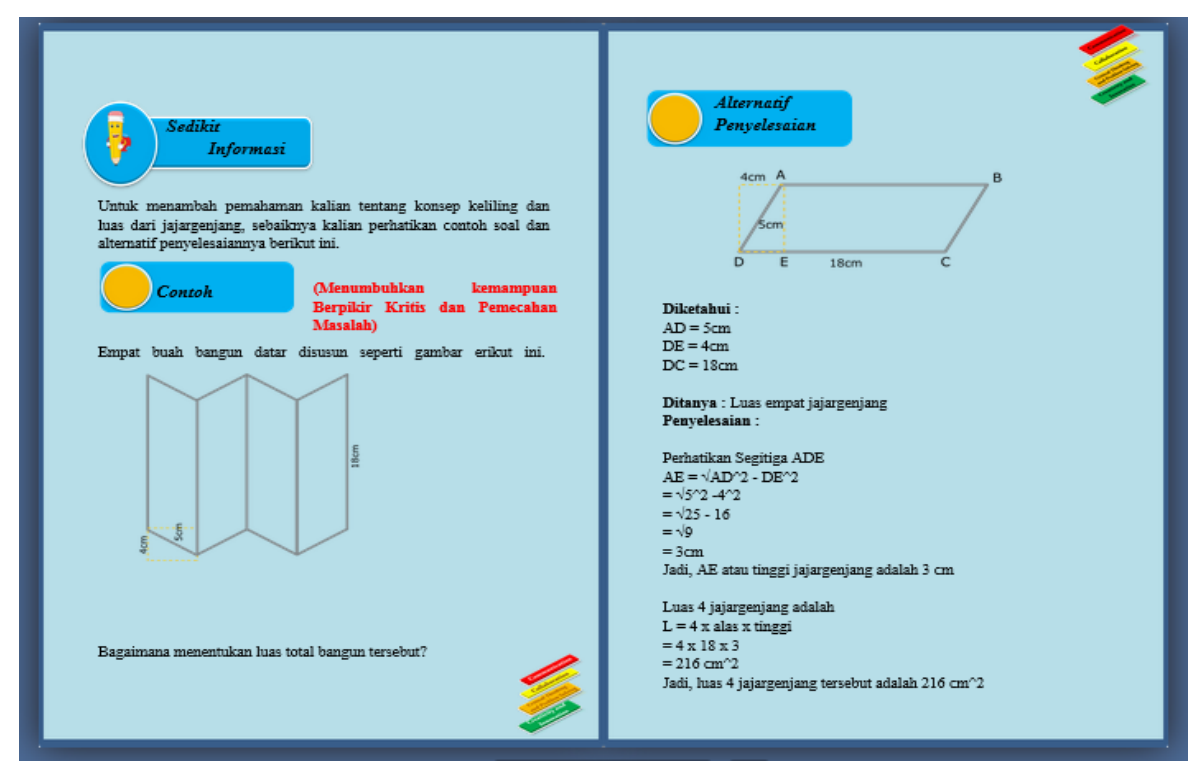

Gambar 5. Contoh Soal dan Penyelesaiannya 


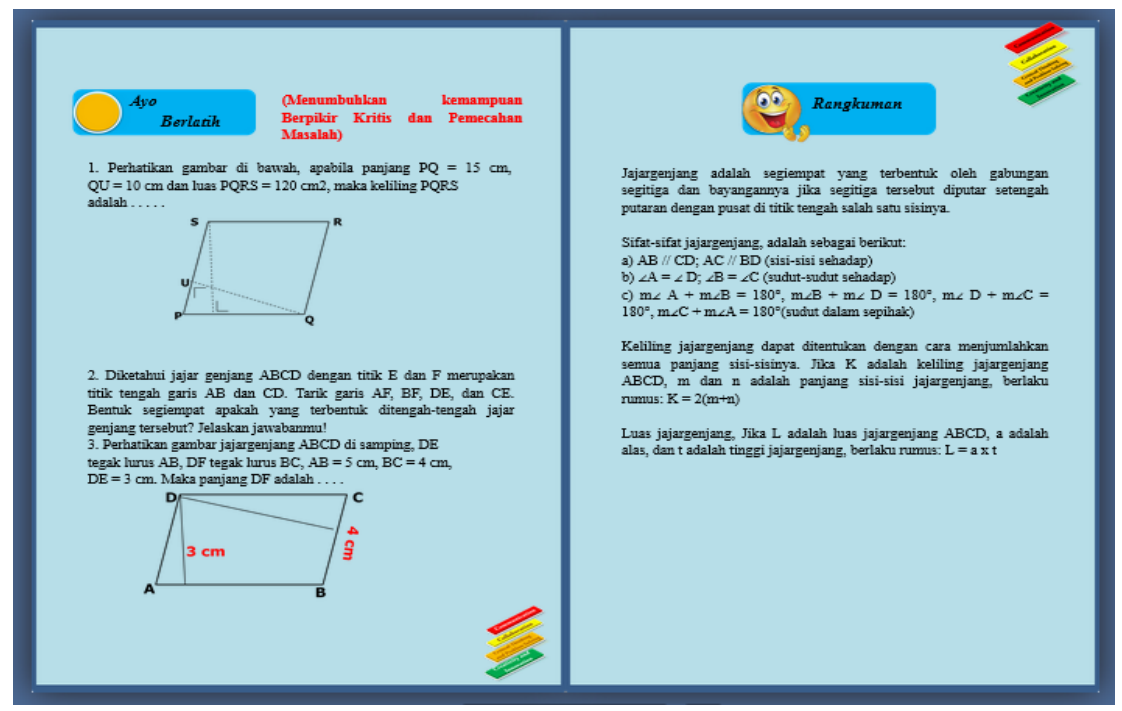

Gambar 6. Ayo Berlatih dan Rangkuman

\section{F. Menu Kuis}

Menu Kuis ini merupakan menu yang didalamnya terdapat 4 soal kuis yang berbasis 4C dilengkapi dengan pengaturan waktu ketika menjawabnya. Ketika pengguna sudah menjawab, soal berikutnya secara otomatis akan ditampilkan. Menu kuis ini juga sebagai uji kompetensi sejauh mana siswa menguasai materi yang telah dipelajarinya. Soal-soal dikutip dari berbagai jurnal yang menganalisis soal berbasis kompetensi 4C.

G. Menu Glosarium

Menu glosarium merupakan halaman yang berisi kosakata sulit yang berkaitan dengan materi maupun kosakata dalam media pembelajaran secara keseluruhan.

H. Menu Daftar Pustaka

Menu ini berisi referensi pengembang dalam membuat media pembelajaran ini.

I. Menu Profil

Menu profil berisi profil singkat pengembang media pembelajaran ini. Terdiri dari data pribadi, riwayat pendidikan dan motto hidup.

J. Menu Penutup

Menu Penutup merupakan halaman untuk keluar dari media pembelajaran ini. Halaman ini ditampilkan ketika pengguna mengklik tombol keluar. 
(7) Uji Ahli

Hasil kelayakan media ajar interaktif powerpoint yang berbasis kompetensi abad 21 diperoleh dari hasil uji ketiga ahli yaitu (media, materi dan bahasa). Ahli media menilai kualitas media dari aspek tampilan visual dan aspek pemrograman. Ahli materi yaitu mengoreksi materi yang keliru dan kurang tepat, aspek yang dinilai yaitu aspek kelayakan isi, aspek kelayakan penyajian dan aspek kompetensi abad 21. Ahli bahasa yaitu menilai bahasa sesuai dengan EYD. Dan masing-masing aspek mendapatkan presentase diatas 70\% dan termasuk kategori sangat layak. Berikut adalah tabel presentase yang didapatkan dari beberapa ahli:

Tabel 1 . Hasil Kelayakan Uji Ahli

\begin{tabular}{cccccc}
\hline No. & Aspek & Skor & Max & \% & Kriteria \\
\hline 1. & Media & 54 & 64 & 87,5 & Sangat Layak \\
2. & Materi & 130 & 160 & 81,25 & Sangat Layak \\
3. & Bahasa & 43 & 52 & 82,69 & Sangat Layak \\
\hline
\end{tabular}

Berdasarkan hasil perhitungan pada tabel diatas maka hasil uji pada ketiga ahli yaitu ahli media, ahli materi dan ahli bahasa menyatakan bahwa media pembelajaran yang dikembangkan sangat layak digunakan untuk kegiatan belajar mengajar matematika.

\section{(8) Uji Coba}

Berdasarkan hasil penelitian relevan yang telah dilakukan oleh peneliti lain yaitu penelitian [9] dan [10], kedua peneliti tersebut menggunakan aplikasi iSpring 7.0 dan hanya menggunakan materi matematika. Maka dari itu pada penelitian kali ini lebih dikembangkan menggunakan aplikasi iSpring 8.0 yang lebih lengkap fiturfitur didalamnya sehingga media pembelajaran yang dihasilkan lebih menarik dan mengaitkan materi matematika yang berbasis kompetensi abad 21 agar lebih menjawab tantangan perkembangan zaman yang lebih maju. Selain itu, penelitian relevan yang lainnya yaitu [5], peneliti tersebut masih menggunakan bahan ajar media cetak sebagai hasil akhir medianya sedangkan pada penelitian kali ini hasil akhir media sudah di publish ke bentuk file web (html) sehingga lebih praktis penggunaanya dan lebih menarik.

Berikut adalah hasil uji coba kepada guru matematika dengan aspek yang dinilai adalah aspek desain pembelajaran abad 21 dan aspek kualitas teknis penggunaan. Hasil ujicoba guru matematika dapat dilihat pada tabel berikut:

Tabel 2. Hasil Uji Coba Guru Matematika

\begin{tabular}{cccccc}
\hline No. & Responden & Skor & Max & \% & Kriteria \\
\hline 1. & Guru 1 & 62 & 80 & 77,5 & Sangat Layak \\
2. & Guru 2 & 73 & 80 & 91,25 & Sangat Layak \\
\hline
\end{tabular}

Berdasarkan hasil perhitungan pada tabel diatas, uji coba yang dilakukan terhadap guru menyatakan bahwa produk yang dikembangkan cukup praktis digunakan baik oleh guru. 


\section{Simpulan}

Berdasarkan pembahasan di atas, maka dapat disimpulkan bahwa media interaktif pada pembelajaran matematika yang berbasis kompetensi abad 21 untuk guru SMP kelas VII yang dikembangkan termasuk kategori sangat baik dan layak menurut penilaian para ahli. Dengan demikian direkomendasikan bagi guru matematika kelas VII agar dapat menggunakan media pembelajaran yang berbasis kompetensi abad 21 ini. Selain itu bagi peneliti lain disarankan untuk melakukan penelitian sampai tahap ke-10 R\&D agar lebih maksimal lagi dalam mengembangkan sebuah media pembelajaran, dan sebaiknya peneliti lain melakukan ujicoba kepada siswa sebagai responden.

\section{Referensi}

[1] Crismono P C 2017 Penggunaan Media dan Sumber Belajar Dari Alam Sekitar Dalam Pembelajaran Matematika Jurnal Gammath 2(2) 72-77

[2] Mustamid \& Raharjo H 2015 Pengaruh Efektifitas Multimedia Pembelajaran Macromedia Flash 8 Terhadap Motivasi Belajar Siswa Pada Materi Fungsi Komposisi Dan Invers EduMa 4(1) 26-42

[3] Yulianti E, Zulkardi \& Siroj R A 2010 Rangkaian Listrik Seri-Paralel Untuk Mengajarkan Logika Matematika Jurnal Pendidikan Matematika 4(1) 26-32

[4] Wibowo E \& Pratiwi D D 2018 Pengembangan Bahan Ajar Menggunakan Aplikasi Kvisoft Flipbook Maker Materi Himpunan Jurnal Matemaika 1(2) 147-156

[5] Maryamah I, Anriani N \& Fathurrohman M 2019 Pengembangan Bahan Ajar Materi Pythagoras yang Berorientasi pada Kompetensi Abad 21 untuk Guru SMP SJME (Supremum Journal Math Education) 3(1) 67-77

[6] Lubis S, Surya E \& Minarni A 2015 Peningkatan Kemampuan Pemecahan Masalah Matematik Dan Kemandirian Belajar Siswa Smp Melalui Model Pembelajaran Berbasis Masalah PARADIKMA 1(3) 110

[7] Sugiyono 2013 Metode Penelitian Pendidikan: Pendekatan Kuantitatif, Kualitatif dan R\&D Bandung: Penerbit Alfabeta

[8] Meredith D, G Joyce P \& B Walter R 2003 Educational Research An Introduction 7th Edition 7th ed (Boston: Allyn \& Bacon)

[9] Suprapti E 2016 Pembelajaran Matematika Model Kooperatif Tipe Stad Dengan Media Powerpoint Ispring Pada Materi Di Kelas VII SMP Jurnal Pendidikan Matematika 1(1) 57-68

[10] Noer J, Kresnadi H \& S Halidjah 2017 Penggunaan Program Ispring 7.0 Dalam Pembelajaran Matematika Untuk Meningkatkan Hasil Belajar Siswa Kelas V Jurnal Pendidikan dan Pembelajaran Khatulistiwa 6(1) 1-12 